\title{
Kommentar
}

\section{Flukten til kroppen - fem refleksjoner om selvskade}

Kristin Ribes tekst er eksemplarisk (1). Med seg selv som eksempel tydeliggjør hun sentrale sider ved selvskadens psykologi. Teksten er kort, men den bidrar med et viktig perspektiv innenfra. De selvpåførte smertene utfordrer våre evner både til å forstå og handle på virksomme måter. Derfor trenger vi de erfarnes hjelp til å forstå mer. Og mye av det er til å fatte (2). Slike innsikter kan igjen være veiledende for terapeutisk holdning og handling.

Jeg anvender Ribes tekst som springbrett, men bruker herfra mine egne ord i ettertankene omkring hennes ord. Jeg velger å trekke frem følgende fem forhold:

Smerten er paradoksal. Smerten er noe vi vanligvis løper fra. Når vi likevel løper etter smerten, er det fordi den kan ha noe å gi. Den fysiske smertens paradoksale kvalitet er at den kan være mentalt smertelindrende. Den kan flytte fokus, og den kan gjøre noe utydelig svært tydelig, både for seg selv eller andre. Følelser er utydelige, mens kroppen er tydelig.

Selvskade uttrykker en skade av selvet. Den selvskadende kan oppleve følelser som uutholdelige. Skriften i huden kan leses som forsøk på å unngå eller regulere vanskelige følelser. Såret er en definert, avgrensbar og synlig skade som gir uttrykk til en indre skade som er vanskeligere å definere, avgrense og å se; og slik kan det hele bli mer utholdelig. Når den indre reguleringen svikter, kan den ytre kroppen bli tildelt rollen som regulator. Kroppen blir mental (3). I fraværet av trygghet kan lidelsen fungere som en beskyttelse. Vi trer tilbake, lukker oss til, søker glemselen eller avleder oss selv.

Helvete er de andre. De vanskelige følelsene i oss stammer i stor grad fra de krevende forholdene mellom oss. Selvskaden kan gjøre vondt verre. Mentalisering er et faglig begrep som viser til evnene til å forstå oss selv og andre, og derigjennom regulere følelser og forhold på gode vis (3). Pasientens sviktende mentalisering av følelser kan smitte over på hjelpernes sviktende mentalisering både av pasienten og av seg selv. Møter med sterke følelser risset inn i kjøtt kan rote det alvorlig til også for oss som er forventet å skulle lindre og fremme vekst. Kristin Ribe forteller om dette. I stedet for empatisk undring og refleksjon kan pasienter bli møtt av de profesjonelles utagering, som kjeft, avvisning, moralisering og sutur uten lokalbedøvelse; «du liker jo smerte».

Redningen er de andre. Selvstendighet er en myte. Vi er alle avhengige. Og de fleste av oss kjenner lengselen etter å bli tålt, selv når vi viser frem det mest skamfulle. Kristin Ribe forteller også om dette i sin tekst. Derfor er den oppløftende. Onde sirkler ble til gode sirkler.

Begynnelsen på et språk. I selvskaden er kroppen blitt et språk for sinnet. Språket er ikke godt nok, fordi det mangler nyanser og rikdom. Men det er et sted vi kan gå videre fra, til et mer nyansert språk. Det nye språket oppstår gjennom samvær og samtale, og det skal ikke være i hud og kjøtt, men i tale, skrift og tegning.

Jeg leser Kristin Ribe slik at dette ikke minst handler om de profesjonelles tålmodighet, toleranse og interesse for at møter skal bli korrigerende følelsesmessige erfaringer. Det dårlig regulerte blir bedre regulert via de regulerende andre. Selvskadende atferd er et problem, men vi bør også forstå at det er et forsøk på en løsning.

\section{Finn Skårderud \\ finns@online.no \\ Høgskolen i Lillehammer \\ 2626 Lillehammer}

Oppgitte interessekonflikter: Ingen.

Litteratur

1. Ribe K. For å kunne være sammen med menneskene rundt meg. Tidsskr Nor Legeforen 2011; 131 484-5.

2. Sommerfeldt B, Skårderud F. Hva er selvskading? Tidsskr Nor Legeforen 2009; 129: 754-8.

3. Skårderud F, Sommerfeldt B. Mentalisering - et nytt teoretisk og terapeutisk begrep. Tidsskr Nor Legeforen 2008; 128: 1066-9.

4. Alexander F. The scope of psychoanalysis. New York, NY: Basic Books, 1961.

Mottatt 2.1. 2011, godkjent 14.1. 2011. Medisinsk redaktør Erlend Hem. 